\title{
Research on Individualized Cultivation Model of Ideological and Political Education of Post 90s College Students
}

\author{
Guan Liyao \\ Qujing Normal University, Qujing City, Yunnan, 655011, China
}

Keywords: Post 90s, Individualized cultivation, Ideological and political education

\begin{abstract}
In recent years, more and more post 90s college students have entered the college campus. In different era background and living environment, post 90s develop their unique characters. It is very necessary to carry out individualized cultivation of ideological and political education for post 90s college students. This paper analyzes the individualized cultivation paths of ideological and political education of post 90s college students, including innovating individualized cultivation content, reforming individualized cultivation approach, optimizing individualized cultivation atmosphere and constructing individualized cultivation platform to provide some references for the relevant researchers.
\end{abstract}

\section{Introduction}

Today, ideological and political education will foster the healthy personality of college students in the socialized environment [1]. Therefore, based on fully respecting the creativity and subjectivity of the educated, ideological and political educators should focus on educator's personality cultivation. The personality described here refers to the relatively stable psychological quality of individuals in the educational environment. The ideological and political education environment is an indispensable objective condition for the growth and development of college students, and any ideological and political education activities are always carried out in a certain ideological and political education environment. People themselves are subjective initiative, can react to environment, positively affect the objective environment, and create a new environment suitable for human survival and development. Therefore, when we are carrying out the individualized development of Ideological and political education, we must first create a personalized development of Ideological and political education environment. The ideological and political education of individualized development is the creative and dynamic development of the educator's moral quality, political accomplishment, activity ability, emotional will and so based on discovering and respecting the existing personality of the educated and making them better in conformity with the thought of a certain society. Germany finally formed an educational practice with excellent personality. As an important part of college teaching, ideological and political education plays a significant role in improving students' Ideological and ideological level. At present, college students in colleges and universities in China are mainly based on the post-90s. Although the post 90s college students have a positive mainstream ideology and have strong innovative ability, they are affected by many factors, and there are also poor independent consciousness and resistance to frustration ability. How to correctly establish the personalized training mode of post 90s college students' ideological and political education is the focus of educators [2].

\section{Unique Personality of Post 90s College Students}

The post 90s college students have received a lot of information. Their thoughts are more precocious. They have their own opinions on things, and do not readily agree with some ideas. The enrichment and creativity of information enable them to have equal communication with teachers, like expressing their own ideas and exploring new ideas and methods. They pursue self and self-confidence and have unique opinions and value judgments on things. They dare to question 
authority and dare to challenge tradition. The post 90s college students had strong subjective consciousness and formed a strong sense of competition. They believe that in school, they should constantly upgrade their ideals and pursuit of life, continue to carry forward the spirit of hard struggle, dare to try, and dare to cultivate self-management consciousness in the competition, improve the level of self-development, and gradually realize their academic goals. But a considerable number of post 90s college students have poor sense of solidarity and cooperation. They don't have strong sense of collectivism and are unwilling to be disciplined. A few students are uncertain about their life goals, lacking confidence in their future and even self-abandonment. Some even feel bored, bored and worried, which leads to an increasing number of excitement, smoking and drinking in life and study. Others appreciate non-mainstream culture, blindly pursue personal freedom and vent their dissatisfaction. At the same time, the post 90s college students gradually formed a good methodology system before entering the University, which laid the foundation for their rapid entry into practice. They often aim at the products and services around them and try to change them. The formation of skepticism and the emergence of novelty seeking provide a strong ideological support for college students to explore and try. The post 90s college students are eager to practice and overturn conventional risks and attempts for any unknown problem or unknown area [3].

\section{Necessity of Individualized Ideological and Political Education of Post 90s College Students}

The post 90s college students are an important part of the post 90s group. On the one hand, they have the commonness of the post 90s group. On the other hand, they are in the unique environment of the university campus, and thus have their own personality. In learning, they have a stronger spirit of suspicion and innovative spirit, showing obvious contradiction to the traditional ideological and political education. They have personal views on complicated social phenomena and like to understand the things they are interested in, learn new knowledge and publish personal views through the network. In life, they publicize their personality and pursue fashion, like straightforward emotional expression, poor self-care ability, and are not good at understanding others. In terms of ideology, their pursuit of independence and freedom, eager to have adult sense, even deliberately mature and aging equipment. But the fact is, the maturity of the surface cannot hide the naive, psychological quality is relatively weak, and the ability to resist setbacks is low. The past ideological and political education is limited by concentrating students on the same theme at the same time and place. However, the education of the network has no time, place, and the limitation of the theme. It provides a wide way for ideological and political education. It broadens the way of education for students and can learn through the network at any time. In the past, the space of Ideological and political education has been widened, and education has become more timeliness and pertinence. The mode of online education not only increases the information content of Ideological and political education, but also improves the quality of education. The convenience of network has greatly improved the efficiency of Ideological and political education. Through the Internet, we can set up a website to publicize personalized ideological and political education, and timely transmit the national guidelines and policies to the post 90s college students. This can effectively mobilize the initiative of post 90s college students to get information and improve the educational level of individualized ideological and political education [4].

\section{Individualized Cultivation Paths of Ideological and Political Education of Post 90s College Students}

\subsection{Innovate Individualized Cultivation Content}

The advent of the new era has brought great significance and opportunities to educational innovation of post 90s college students. First, it enriched the educational content of Ideological and political education. Before the advent of the new era, the ideological and political education of college students is mainly focused on helping students to understand the history of the party, Chinese ancient modern history, the establishment of correct values and outlook on life in real social life. 
However, the emergence of the network era makes educators must pay attention to the negative effects of network on the emergence of college students. Building experiential teaching practice environment and trying to keep it within a controllable range will help enhance the factual persuasiveness of Ideological and political education. Therefore, in the process of Ideological and political education, we should actively guide students to establish correct network values, teach them how to identify network information, promote healthy network ethics and norms, and guide students to use the network correctly. The practice of Ideological and political theory consists of three parts: ideological improvement, social service and ability training. The practice of thinking promotion includes learning important literature, reading classic works, watching film and television works, listening to academic reports, discussing special topics, visiting and studying. Students can choose from them independently and guide the post 90 s college students to integrate the socialist core values into their daily learning and life. The practice of social services includes public welfare, popular science and volunteer service activities. In addition to the necessary selection of public welfare work, students are selected to improve their cognitive level through cognition, experience, perception and practice. The practice of ability training includes educational activities, agricultural activities, school business activities and social research activities. Students choose one of them. Through short-term training, post internship, and demand survey, the students' personality growth and personality potential can be improved.

\subsection{Reform Individualized Cultivation Approach}

Colleges need to gradually transform their old ways of Ideological and political education and adopt diversified teaching forms and advanced teaching means to carry out ideological and political teaching. This can solve the problems of post 90s college students in their ideology and cultivate their good way of thinking. In the development of society, the methods and means of ideological and political education also need to carry out corresponding reform and innovation. Teachers need to understand the specific situation of students in depth, which can be targeted and reasonable in the process of Ideological and political teaching. In the actual teaching process, many examples of novel themes and peculiar ideas are selected to communicate with the students, and the ideological and political education is carried out by common discussion or students preparing lessons and showing the results of the class. The traditional education is unable to comply with the needs of the post $90 \mathrm{~s}$ college students. The teachers should attach importance to the study of the cognitive mode and thinking mode of the post 90s college students. The teachers and students can form a harmonious and good communication and interaction relationship between teachers and students. It becomes an interactive and experiential two-way interactive teaching mode, which makes the classroom of Ideological and political teaching become an important platform for free discussion and equal communication between teachers and students. The arrival of the new era has created a new educational atmosphere for the ideological and political education.

\subsection{Optimize Individualized Cultivation Atmosphere}

The post 90s college students live in a new era of information, which is developing rapidly in the new media. The Internet has become an indispensable part of their life. Taking full advantage of the network platform and taking the network as the main position of Ideological and political education, we can communicate well with the students to close the distance between the students and the students. To guide students to use micro-blog and WeChat to open the special topics of Ideological and political education for the post 90s college students, such as the party building, the post station, employment guidance, inspirational forum, academic education, Thanksgiving education, and special activities. We should develop new media culture that is ideological, intellectual, interesting and service oriented. The post 90s college students, influenced by the environment of the social environment and the family environment, often have certain particularity in the ideological aspect, thus increasing the difficulty of Ideological and political education in Colleges and universities. Colleges and universities need to pay attention to the integration of theory and practice in ideological and political education and improve the post-90s. Students' Ideological and political consciousness 
will further enhance the effectiveness of Ideological and political teaching. In the process of Ideological and political education, teachers should implement targeted educational practice in accordance with the actual situation and specific needs of the students, gradually stimulate the enthusiasm and initiative of students to participate in the teaching, so that students can accept the edification of Ideological and political education in the practice of educational practice, thus cultivating students' good quality. The ideological and political quality. In classroom teaching, teachers should pay attention to communication with students. Group teaching is also needed to organize students to cooperate in group exploration. Good communication has built a harmonious and good relationship between teachers and students to lay a good foundation for improving the effectiveness of Ideological and political classroom teaching.

\subsection{Construct Individualized Cultivation Platform}

The traditional ideological and political education is mainly through face-to-face classroom teaching methods to help students set up a correct outlook on life and values. However, with the emergence of the network and the emphasis on the ideological and political education of the post 90s college students in China, some ideological and political education websites have been developed, thus for ideological and political education. The workers provide detailed reports on Ideological and political education, which enriches the educational channels of Ideological and political education. Teachers can pass information through multimedia representation, such as sound, image, animation, video and so on. Organize students to watch patriotic films and public service ads to stimulate students' interest in learning, they can also guide students to the mainstream value orientation and help students to set up a correct outlook on life and values. The online education platform has the functions of both creative joy sharing, successful case analysis of Ideological and political education, innovation and frustration, innovation and interesting sharing, and information dissemination of innovation results. The construction of the offline platform is mainly to make up for the shortcomings of the online platform, and to highlight the characteristics of the face-to-face communication. The basic forms of the field workshop, innovation lecture, innovation sharing, experience exchange, and the establishment of innovative team are the basic forms. The combination of experience and communication should focus not only on theory but also on practice. The Innovation workshop is a complex platform for innovative ideas, innovation experience exchange, innovation results analysis, innovation and setback and guidance of innovation guidance. It is an ideological and political education platform in history.

\section{Conclusion}

The post 90s college students are the main force of our country's future construction. Colleges and universities need to pay attention to the ideological and political education of the post 90s college students, to better promote the overall development of the post 90s college students and to cultivate their good ideological and political quality, so that they can better serve the cause of socialist modernization in China. The individualized cultivation of ideological and political education in colleges should truly realize the personalized cultivation of efficient ideological and political education.

\section{References}

[1] Wei Huanyu. Exploration on the Ideological and Political Education Model for "Post-90s" University Students [J]. The Science Education Article Collects, 2016(6): 5-6.

[2] Xia Boyi. A Probe into the Attractiveness of the Ideological and Political Education of the Post 90s College Students [J]. Central China Normal University Journal of Postgraduates, 2013, 20(4): 141-144.

[3] Zhong Hongyu. On the individualistic political education of the post 90s [J]. Journal of 
Shijiazhuang Vocational Technology Institute, 2016, 28(1): 78-80.

[4] Zhang Yucheng, Jiang Hui. On the Ideological and Political Education of "Post-90" Undergraduates in Microblog Environment [J]. Journal of Yangzhou University (Higher Education Study Edition), 2013, 17(4): 32-35. 